\title{
Transection of Spinal Cord
}

\section{A Rare Obstetrical Complication of Cephalic Delivery}

\author{
STANFORD T. SHULMAN, ${ }^{\star}$ JOHN D. MADDEN, JOHN R. ESTERLY, and \\ DOUGLAS R. SHANKLIN
}

From the Departments of Pediatrics, Pathology, and Obstetrics and Gynecology, University of Chicago; and the Laboratory of Pathology, Chicago Lying-in Hospital, Chicago, Illinois, U.S.A.

Shulman, S. T., Madden, J. D., Shanklin, D. R., and Esterly, J. R. (1971). Archives of Disease in Childhood, 46, 291. Transection of the spinal cord: a rare obstetrical complication of cephalic delivery. A newborn infant, delivered following mid-forceps rotation, presented with apnoea, anaesthesia below the level of the mid-neck, and flaccid quadriplegia. At necropsy there was transection of the cord, and atlanto-occipital and atlantoaxial dislocations. Cord injury usually follows breech presentation, the lesion is in the lower cervical or upper thoracic segments, and results from excessive traction. By contrast, in the rare cases following cephalic delivery, the lesion is most often in the upper cervica! cord and probably results from rotational forces.

A century ago, Parrot (1870) reported the clinical and pathological findings in a 3-day-old baby with cervical spinal cord damage evidenced by intact spinal reflexes and quadriplegia. Necropsy findings included meningeal lacerations and $\mathrm{C}_{6.7}$ cord transection. He related the lesions to the difficult breech delivery, during which 'un craquement très-fort' had been heard from within the birth canal. Spinal cord injury had been noted previously in the nineteenth century. Kennedy (1836), Billard (1839), Weber (1851), and Little (1862) referred to spinal cord pathology, but only Billard (1839) considered such lesions a direct result of labour.

Newborn babies with spinal cord injuries surviving the neonatal period were first documented in the early 1900's (Handwerck, 1901; Beevor, 1902; Gött, 1909; Lawatschek, 1911; Burr, 1920). Survival into childhood was first reported in the 1920's (Kooy, 1920; Kohlbry, 1923; Valentin, 1924).

The classic articles on intrapartum spinal cord injury appeared between 1921 and 1927 (Crothers, 1922 and 1923a, b; Ford, 1925; Crothers and Putnam, 1927; Ford, Crothers and Putnam, 1927), revealing that the vast majority of cases followed

\footnotetext{
Received 5 December 1970.

^Present address: Department of Pediatrics, University of Florida College of Medicine, Gainesville, Florida 32601.

Supported by the Developmental Physiology Training Grant, NIH T1-HD0054, Department of Pediatrics, University of Florida (Trainee, Dr. Shulman).
}

traumatic breech delivery. Crothers and Putnam (1927) reported 7 cases following cephalic delivery and 7 more from the literature (Jolly, 1895; Couvelaire, 1903; Stoltzenberg, 1911; Belfrage, 1923), and cited necropsy findings of spinal cord haemorrhage in 6 of 16 cephalic stillborn infants (Spencer, 1891). There have been only 3 subsequent reports of spinal cord injury with cephalic delivery, including but a single article in the English literature (Table I) (Föderl, 1931; Herzog, 1952; Towbin, 1964).

\section{Case Report}

A mature, $2500 \mathrm{~g}$ infant male was born to a gravida II, para I, 35-year-old black woman in the 39th week of gestation. The onset of labour was spontaneous but there was a history of rupture of the membranes two days before admission. Dilatation and effacement were uneventful. $50 \mathrm{mg}$ pethidine was given two hours before delivery. Presentation was cephalic, in the occiput posterior position, and a mid-forceps rotation was performed under methoxyflurane anaesthesia. The second stage of labour was uneventful.

The Apgar score was 3 at one minute and 4 at five minutes. The heart rate was 120 , but the infant was flaccid and failed to breathe spontaneously. With positive pressure oxygen, he became pink and maintained a normal cardiac rate, but made no respiratory effort. Over the next two hours there was no change in his condition despite intravenous nalorphine, levallorphan, and caffeine. 
TABLE

Spinal Cord Injury Associated With Cephalic Delivery

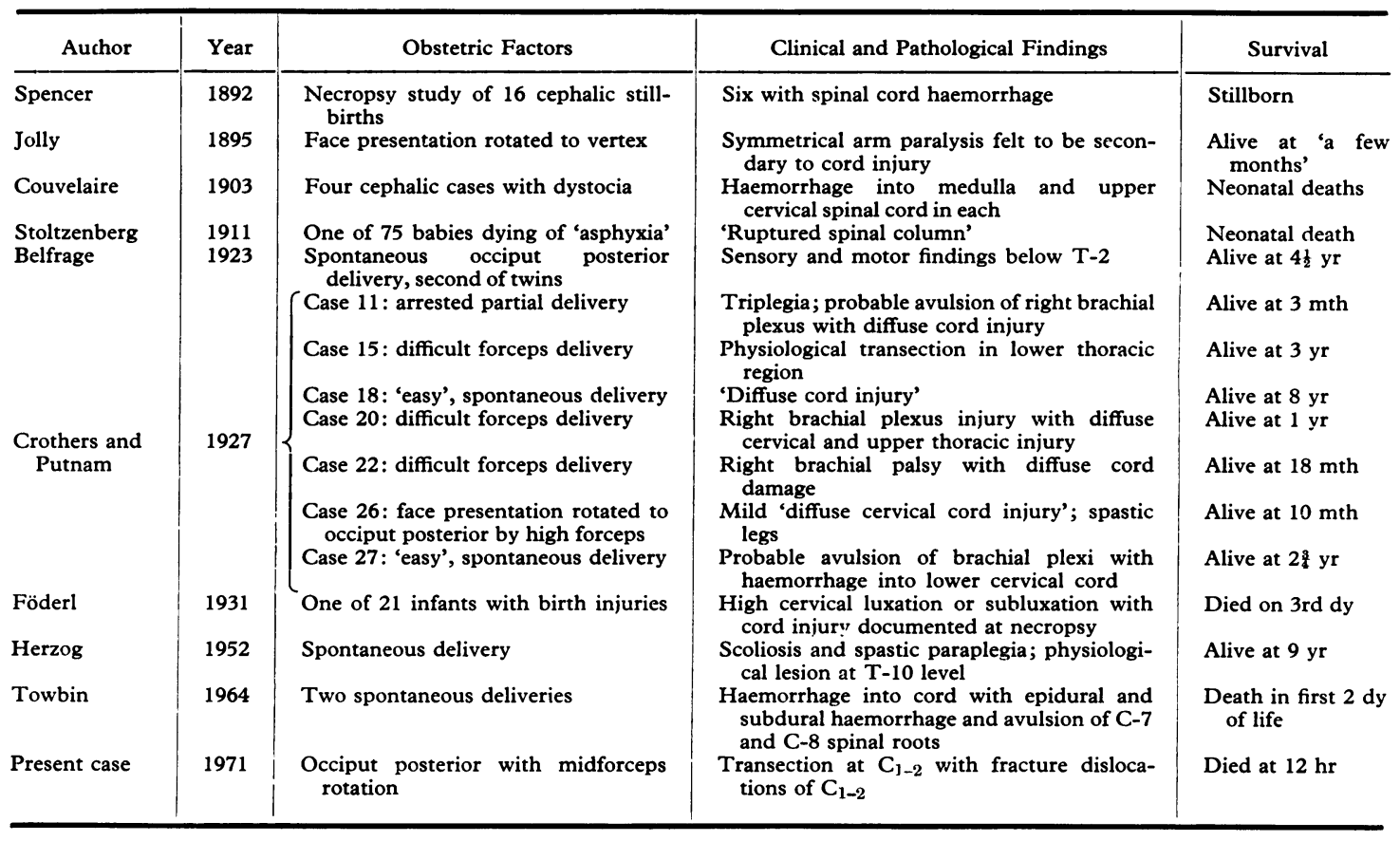

By the third hour, he was intubated and placed on a respirator. Though his extremities were flaccid, he was alert, moved his head and eyes, and had a suck reflex. A systolic heart murmur was heard. Priapism and withdrawal responses to painful stimuli in all limbs were noted at 6 hours of age, but he was otherwise unchanged and he did not move his extremities spontaneously. Absent sweating and no evidence of sensation (other than withdrawal responses to deep pain) were noted below the level of mid-neck. Priapism was persistent. $X$-rays of the cervical spine showed probable atlantoaxial and atlanto-occipital dislocations without obvious fractures.

Because of the radiological evidence of vertebral dislocations and clinical evidence of cervical spinal cord injury, the infant was placed in traction with chin straps. Within 15 minutes, however, he developed bradycardia which was irreversible despite removal from traction. He died shortly thereafter, 12 hours after birth.

At necropsy a cephalohaematoma was present over the right parietal region. The brain stem was surrounded by blood clots. The medulla and occipital lobes were also blood-stained, and the spinal fluid was grossly bloody. Discontinuity of the spinal cord and haemorrhage in the epidural and subarachnoid spaces were found at the level of $\mathrm{C1}, 2$. The atlas and axis were freely movable, and on subsequent dissection, a fracture of the odontoid process of the axis was demonstrated.

Histological sections of the proximal and distal portions of the cord showed extravasated blood and a leucocytic infiltration between the nerve fibres. Necrosis and neuronal chromatolysis were found here and in the sections from the brain stem. Other findings included an acute chorioamnionitis, aspirated squames, and petechial haemorrhages and foci of polymorphonuclear cells in the lung. The degree of glycogen depletion and reduced haematopoiesis in the liver was compatible with mild intrapartum distress.

\section{Discussion}

Incidence. Severe spinal cord injury following cephalic delivery is decidedly uncommon. Mild injury appears to be frequent, though most neonatal necropsies do not routinely include an examination of the spinal cord. In a series of $600 \mathrm{fetal}$ and neonatal necropsies with brain and cord examination, Towbin (1970) found evidence of significant spinal or brain stem injury in over $10 \%$. The lesions include spinal epidural haemorrhage, meningeal laceration, and trauma to the nerve roots, arteries, ligaments, vertebral bodies, and even to the paraspinal musculature (Towbin, 1970; Schwartz, 1961).

Mechanism of injury. The spinal cord is firmly anchored by the cauda equina and the 
brachial plexi but is only loosely attached to the dura in the thoracolumbar region. The neonatal vertebral column is poorly ossified and less rigid than in the older infant (Stern and Rand, 1959), and the cord is relatively less elastic than its encasement, documented by direct observations on decapitation of mature stillborn infants by linear tension (Duncan, 1874).

In breech presentations it is clear that the mechanism of injury is related to stretch injury. These injuries can occur in any spinal cord region (Zellweger, 1945), though lower cervical and/or upper thoracic lesions are most common (Ford, 1925; Schwartz, 1961; Stern and Rand, 1959; Leventhal, 1960). Because of the frequency of vertebral displacement, however, Potter (1961) concluded that crush injury might also play a role in cord damage after breech delivery.

The mechanism of injury during cephalic delivery is less obvious. Difficult or prolonged labour is often noted, and occasionally (as in the present patient) there is a history of rotational manipulation; in these infants it is clear that injury resulted from excessive torsion rather than traction. With forceps extraction, stretch forces may also play a role. The site of cord injury in cephalic presentation is nearly always cephalad to the brachial attachments, most compatible with the hypothesis of torsion injury. This is in contrast to the more caudad lesions due to traction injury.

Fetal malposition, such as face or brow presentation or in utero opisthotonos or 'flying fetus', may render the fetus vulnerable to unphysiological force (Knowlton, 1938; Melody, 1948; Taylor, 1948). Likewise, congenital vertebral anomalies may predispose to injury (Föderl, 1931; Zellweger, 1945). Indeed, $x$-rays in infants with suspected cord injury may be of more value in ruling out congenital spinal anomalies than in diagnosing vertebral fracture and/or dislocation because of the sparsely ossified spinal column and the difficulty in positioning ill infants (Crothers, 1959; Stern and Rand, 1959; Ford, 1966).

Clinical features. Most liveborn infants with intrapartum cord injuries die in the early neonatal period from respiratory problems or associated brainstem injury. As in the present case, apnoea may be the dominant symptom in patients with lesions cephalad to the phrenic nuclei $\left(\mathrm{C}_{3}-\mathrm{C}_{5}\right)$ (Crothers and Putnam, 1927; Zellweger, 1945). Because of the more caudad lesions produced, apnoea is rarely present after breech cord injury.

Several clinical syndromes appear in surviving infants (Crothers, 1959): (a) unilateral or bilateral brachial palsies and/or cranial nerve deficits, (b) permanent flaccidity and anaesthesia below the level of physiological (and/or anatomical) cord transection, and (c) initial flaccidity and anaesthesia (spinal shock) but with the subsequent development of lively spinal reflexes (Head and Riddoch, 1917). In addition, there may be less severe lesions with partial physiological cord transection and varying amounts of destruction of ascending or descending tracts. The return of reflex activity after a period of spinal shock depends upon the absence of significant damage in the distal cord segment. In the present patient, spinal shock was not found; it has been suggested that children have an earlier and more active return of reflex activity (Ford, 1925).

The lesions in these cord injuries extend over many vertebral segments (Crothers and Putnam, 1927; Stern and Rand, 1959), and the diagnosis in the neonate requires the presence of non-selective, non-progressive neurological signs, most often with a history of a difficult, usually breech, delivery (Crothers and Putnam, 1927; Leventhal, 1960).

Though priapism may be present in any patient with spinal cord lesion (most commonly in those with cervical lesions or with transection, Austin, 1961), this sign has not been previously reported in cord injury in the newborn. The mechanism of priapism in these injuries may be related to sympathetic vasopressor interruption, leading to penial engorgement.

\section{Conclusions}

Serious and even lethal spinal cord lesions can and do occasionally result from obstetrical injury to the fetus. In breech deliveries, injury to the cord may result from excessive longitudinal traction. With cephalic presentation, spinal cord lesions are considerably less common, and the mechanism is often unclear. The case presented here is probably unique in that cord transection most likely resulted from the shearing forces associated with a forceps rotation of the head of 180 degrees. Since many infants with less severe injuries survive the neonatal period, the prompt recognition of spinal cord lesions is essential.

Correspondence to Dr. S. T. Shulman, Department of Pediatrics, University of Florida, Gainesville, Florida, U.S.A. 32601 .

REFERENCES

Austin, G. M. (1961). The Spinal Cord, p. 15. C. C. Thomas, Springfield, Illinois.

Beevor, C. E. (1902). A case of congenital spinal muscular atrophy (family type), and a case of haemorrhage into the spinal cord at birth, giving similar symptoms. Brain, 25, 85 .

Belfrage, H. (1923). Ein Fall von geburtstraumatischer Querschnittsläsion des Rückenmarkes. Acta Paediatrica, 3, 91. 
Billard, C. M. (1839). A Treatise on the Diseases of Infants, Founded on Recent Clinical Observations and Investigations in Pathological Anatomy, Made at the Hospice des Enfans-Trouvés: with a Dissertation on the Viability of the Child. Translated from the third French edition with an appendix by J. Stewart, p. 472. Adlard, New York.

Burr, C. W. (1920). Hemorrhage into the spinal cord at birth. American fournal of Diseases of Children, 19, 473.

Couvelaire, A. (1903). Hémorragies du système nerveux central des nouveau-nés dans leurs rapports avec la naissance prématurée et l'accouchement laborieux. Annales de Gynécologie et d'Obstétrique, 59, 253.

Crothers, B. (1922). The effect of breech extraction upon the central nervous system of the fetus. Medical Clinics of North America, 5, 1287.

Crothers, B. (1923a). Injury of the spinal cord in breech extraction as an important cause of fetal death and paraplegia in childhood. American fournal of the Medical Sciences, 165, 94.

Crothers, B. (1923b). Changes of pressure inside the fetal craniovertebral cavity. Surgery, Gynecology and Obstetrics, 37, 790.

Crothers, B. (1959). Paralysis due to birth injury of the spinal cord. In Practice of Pediatrics, 4th ed., p. 13. Ed. by J. Brenneman and I. McQuarrie. Prior, Hagerstown, Maryland.

Crothers, B., and Putnam, M. C. (1927). Obstetrical injuries of the spinal cord. Medicine, 6, 41 .

Duncan, J. M. (1874). Laboratory note: on the tensile strength of the fresh adult foetus. British Medical fournal, 2, 763.

Föderl, V. (1931). Die Halsmarkquetschung, eine Unterart der geburtstraumatischen Schädigung des Zentralnervensystems. Archiv für Gynäkologie, 143, 598.

Ford, F. R. (1925). Breech delivery in its possible relations to injury of the spinal cord, with special reference to infantile paraplegia. Archives of Neurology and Psychiatry, 14, 742.

Ford, F. R. (1966). Diseases of the Nervous System in Infancy, Childhood and Adolescence, 5th ed., p. $1059 . \quad$ C. C. Thomas, Springfield, Illinois.

Ford, F. R., Crothers, B., and Putnam, M. C. (1927). Birth Injuries of the Central Nervous System. Medicine Monographs, vol. XI. Williams and Wilkins, Baltimore.

Gött, T. (1909). Ueber einen seltenen Lähmungstypus nach Geburtstrauma. Fahrbuch für Kinderklinik, 19, 422.

Handwerck, C. (1901). Zur pathologischen Anatomie der durch Dystokie entstandenen Rückenmarksläsion. Virchows Archiv für pathologische Anatomie und Physiologie und für klinische Medicin, 164, 169.

Head, H., and Riddoch, G. (1917). The automatic bladder, excessive sweating and some other reflex conditions, in gross injuries of the spinal cord. Brain, 40, 188.

Herzog, R. (1952). Spätbild einer geburtstraumatischen Hämatomyelie. Zeitschrift für Orthopaedie und ihre Grenzgebiete, 82,477 .

Jolly, F. (1895). Comment on birth injury, in Berliner Gesellschaft für Psychiatrie and nervenkrankheiten. Zentralblatt für Neurochirurgie, 14, 792.
Kennedy, E. (1836). Observations on cerebral and spinal apoplexy, paralysis, and convulsions of new-born infants. Dublin fournal of Medical Science, 10, 419.

Knowlton, R. W. (1938). A flying foetus. Fournal of Obstetrics and Gynaecology of the British Empire, 45, 834.

Kohlbry, C. O. (1923). Birth hemorrhage into the spinal cord with resultant bladder and kidney complications. American Fournal of Diseases of Children, 26, 242.

Kooy, F. H. (1920). Rupture of the spinal cord in dystocia. fournal of Nervous and Mental Diseases, 52, 1.

Lawatschek, R. (1911). Ein Fall von Hämatomyelie mit completter Leitungsunterbrechung bei einen Neugeborenen mit viermonatlicher Lebensdauer. Archiv für Kinderheilkunde, 56, 1.

Leventhal, H. R. (1960). Birth injuries of the spinal cord. Fournal of Pediatrics, 56, 447.

Little, W. J. (1862). On the influence of abnormal parturition, difficult labours, premature birth, and asphyxia neonatorum, on the mental and physical condition of the child, especially in relation to deformities. Transactions of the Obstetrical Society of London, 3, 293.

Melody, G. F. (1948). Opisthotonos fetalis in breech presentation report of a case with bilateral congenital posterior dislocation of the tibiae. California Medicine, 68, 378.

Parrot, J. (1870). Note sur un cas de rupture de la moelle, chez un nouveau-né, par suite de manoeuvres pendant l'accouchment. Union Médical, 9, 137.

Potter, E. L. (1961). Pathology of the Fetus and Infant, 2nd ed., p. 102. Yearbook Medical Publishers, Chicago.

Schwartz, P. (1961). Birth Injuries of the Newborn, p. 13. Hafner, New York. Karger, Basle.

Spencer, H. R. (1892). On visceral haemorrhages in stillborn children. An analysis of 130 autopsies; being a contribution to the study of the causation of stillbirth. Transactions of the Obstetrical Society of London, 33, 203.

Stern, W. E., and Rand, R. W. (1959). Birth injuries to the spinal cord. A report of 2 cases and review of the literature. American Fournal of Obstetrics and Gynecology, 78, 498.

Stoltzenberg: F. (1911). Zerreissungen der intervertebralen Gelenk kapseln der Halswirbelsäule eine typische Geburtsverletzung. Klinische Wochenschrift, 48, 1741.

Taylor, J. C. (1948). Breech presentation with hyperextension of the neck and intrauterine dislocation of cervical vertebrae. American fournal of Obstetrics and Gynecology, 56, 381.

Towbin, A. (1964). Spinal cord and brain stem injury at birth. Archives of Pathology, 77, 620.

Towbin, A. (1970). Central nervous system damage in the human fetus and newborn infant. American fournal of Diseases of Children, 119, 529.

Valentin, H. (1924). Pathologisch-anatomische Beiträge zur Kenntnis der Geburtslähmung. Zeitschrift für Orthopaedische Chirurgie, 45, 337.

Weber, F. (1851). Beiträge zur pathologischen Anatomie der Neugeboreren. C. Shröder, Kiel.

Zellweger, H. (1945). Ueber geburtstraumatische Rückenmarkslaesionen. Helvetica Paediatrica Acta, 1, 13. 